\title{
THE NATIONAL CENTRAL LIBRARY
}

\begin{abstract}
$\mathrm{T}$ HE twenty-fourth annual report of the Executive Committee of the National Central Library covers the year 1939-40 and indicates the important contribution the Library is making to the nation's war effort. It is a centre which is used by Government Departments, research stations and industrial concerns and a channel through which books immediately essential for war purposes are being regularly supplied. At the same time it is ensuring that essential information is regularly available for those engaged in agriculture, trade and business of all descriptions. Among special war work now being done by the Library mention may be made of assistance given by lending books to the camp libraries which are being established in connexion with the Lord Mayor of London's Services' Libraries and Book Fund by supplying bibliographical information to the Prisoners of War Book Service and by assisting the Sea War Library Service which supplies books to men serving in the Royal Navy and Mercantile Marine.

In July 1939 the Treasury announced that its grant to the Library for the year $1939-40$ was to be reduced from $£ 5,000$ to $£ 4,800$, but a special grant of $£ 100$ has been provided by both the Governors of the Thomas Wall Trust and the Trustees of the Cassel Educational Trust to meet this deficit. The Treasury has since announced, in December 1939, that the grant-in-aid for the year 1940-41 is to be limited to $£ 3,500$, but this deficit has been met by an emergency grant from the Rockefeller Foundation of 8,500 dollars for the year 1940-41. The number of volumes in the Library was increased during the year from 161,383 to 170,972 and the total number of books issued during the year was 50,611, including 1,191 books issued to adult classes. After the first few weeks of the War there was a steady increase in the number of applications received as well as in the percentage of important books asked for and the requests for bibliographical information. The group of Outlier Libraries now includes 114 special libraries, 2 urban libraries which are not yet co operating in a
\end{abstract}

regional system and 19 London borough libraries. During the year the Bibliographical Society and the British Social Hygiene Council were added to these special libraries. A total of 491 libraries is now co-operating in the regional system and there are only 24 urban libraries serving a population of more than 20,000 which are not co-operating in this system.

The number of books issued to university libraries, excluding those issued to adult classes, decreased to 3,046 during the year, and 4,440 books were lent by the university libraries to other libraries through the national system. Books borrowed from libraries in other countries for the use of libraries in the British Isles decreased to 159 compared with 283 in the previous year.

Owing to the risk of destruction of property in the centre of London all the Union Catalogues as well as all other irreplaceable or scarce bibliographical material were moved early in September 1939 to Bourne Lodge, Bourne End, Hemel Hempstead, the non-bibliographical books and books belonging to the adult class department being left at Malet Place. This was among the buildings in London recently destroyed by enemy action, and although a large number of books have been saved, many thousands have been destroyed, including the whole of the books in the adult class department and many long and valuable sets of publications. This loss is serious not only to the National Central Library itself but also to all other libraries in the British Isles which depend upon it for the books they are unable to supply from their own shelves.

The Library is still able to give its unique service in arranging loans of books between libraries, the total number of volumes upon which it is able to draw for this purpose being no fewer than 21,000,000. The Trustees have already made arrangements to continue the full work of the Library and it is hoped that funds may be forthcoming to enable them to replace the more urgently wanted books.

\section{NATURAL GAS IN ONTARIO}

\begin{abstract}
$\mathrm{I}^{\mathrm{N}}$ view of the present more or less acute natural gas situation, J. F. Caley has anticipated a comprehensive memoir (now in the Press) by a brief mimeographed report on natural gas in Brantford Area, Ontario*. The report has actually been condensed from the more detailed work and is intended to be an up-to-date guide to operators and others interested in the particular area.

The region known as Brantford area extends for approximately $\mathbf{4 , 8 0 0}$ square miles from Dundas in the east to Aylmer in the west, and from Mount Forest in the north to the shore of Lake Erie in the south. Commercial production of natural gas is obtained from that part of the area lying south of * Canada Department of Mines and Resources. Mines and Geology
Branch, Geological Survey Paper 40-42. Preliminary Report: Natural Gas in Brantford Area, Ontario. J. F. Caley. Pp. ii $+31+1$ map. (Ottawa : King's Printer, 1940.)
\end{abstract}

an east-west line drawn through Paris and comes entirely from rocks of Silurian age, namely, the Medina, Clinton and Guelph formations. Actual productive horizons involved are the fine- to mediumgrained sandstones of the Whirlpool (White Medina); light grey and red sandstone and sandy shale of the Grimsby (Red Medina); grey and buff crystalline or granular limestone of the Clinton; and the grey, buff or cream-coloured, crystalline and finely granular dolomite found in the upper part of the Guelph formation.

A map showing structure contours drawn on top of the Clinton and accompanying the report shows that regional structure is monoclinal and has a southerly dip averaging approximately $24 \mathrm{ft}$. a mile over the whole producing area. Such variations in rate and direction of dip as oceur have been caused 